Paedagogia Christiana

I/39 (2017) - ISSN 1505-6872

\title{
Małgorzata Wałejko, Osobno i razem. Personalistyczne wychowanie do samotności i wspólnoty, Szczecin: Wydawnictwo Naukowe Uniwersytetu Szczecińskiego, 2016, s. 357.
}

DOI: http://dx.doi.org/10.12775/PCh.2017.017

Monografia autorska Małgorzaty Wałejko stanowi obszerne dzieło na temat możliwości i potrzeby integrowania $\mathrm{w}$ dziele wychowania dwóch zasadniczych wymiarów ludzkiej egzystencji: samotności i wspólnotowości. Przesłanie to jest przekazane przez Autorkę w sposób niezwykle oryginalny. Można powiedzieć, że pośród badaczy świata humanistyki mało kto pisze w ten sposób. Cóż to za sposób? O niepowtarzalnej wartości i oryginalności sposobu tworzenia recenzowanej pracy decydują - w mojej opinii - poniżej przedstawione walory.

Po pierwsze: Autorka tworzy dzieło przepojone myślą filozoficzną, w którym widoczny jest jej wysiłek fenomenologiczno-hermeneutyczny, związany z dociekaniem istoty samotności oraz wspólnotowości oraz odczytywaniem nadawanych im indywidualnie i kulturowo znaczeń. Z tej racji poważnego wysiłku intelektualnego i duchowego wymaga również czytanie tej pracy. Czytelnik, który chce zrozumieć drogę dochodzenia Autorki do kolejnych odkryć, musi zdobyć się na kontemplowanie (a nie szybkie czytanie) przedstawianych treści. $Z$ tego względu praca ta wymaga podobnego trudu studiowania jak na przykład filozoficzne dzieło Karola Wojtyły Osoba i czyn, które nie sposób przeczytać ,jednym tchem”, a do którego zresztą Autorka odwołuje się na kartach swojej pracy wielokrotnie.

Po drugie: w recenzowanej pracy znaczącym jej elementem stała się myśl teologiczna. Autorce nie chodziło jednak o to - jak sądzę - by nadać swojemu dziełu częściowo charakter teologiczny, ale, by czerpiąc z myśli teologicznej, w sposób maksymalnie pełny skorzystać z wszystkich możli- 
wości wythumaczenia badanych przez siebie aspektów istnienia i działania człowieka - uczestnika wychowania. Dociekając ich istoty, Autorka znajduje w teologii chrześcijańskiej, a także w katolickiej nauce społecznej najpełniejsze wyjaśnienie źródeł samotności człowieka oraz jego tęsknoty za drugim człowiekiem. Nie każdy czytelnik musi się zgodzić z tym odczytaniem, ale warto wyzbyć się osobistych idiosynkrazji, by zrozumieć głębię chrześcijańskiego ujęcia tej bodaj najważniejszej w życiu człowieka ambiwalencji, jaką jest z jednej strony osobność i zamknięcie się w swoim ,ja”, a z drugiej strony dążenie do bycia z innym, dążenie do wspólnoty.

Wykorzystanie myśli teologicznej jest tu też niewątpliwie wyrazem uznania przez Autorkę religijnego wymiaru ludzkiej egzystencji. Luigi Giussani mówił o istnieniu u człowieka „zmysłu religijnego”, który wiąże się $\mathrm{z}$ dążeniem człowieka do odczytania sensu własnego życia w perspektywie Absolutu. Kulturowy nakaz zniknięcia czy wyciszenia tego dążenia nie zmienia faktu, że ów zmysł jest jedną z najbardziej dynamicznych sił rządzących ludzką aktywnością. Niezauważanie jej czy rezygnacja przez humanistów z głębokich analiz dynamiki owej siły przyczyniają się do zredukowania obrazu człowieczeństwa, do błędnej percepcji realnego człowieka.

Po trzecie: warsztat filozoficzny, o którym mowa w pierwszym punkcie charakterystyki sposobu pisania recenzowanego dzieła, jest niejako „łamany" przez inne odmiany ludzkiej wiedzy. Przede wszystkim na pierwszy plan wychodzi tu wiedza naukowa z zakresu psychologii, biologii, medycyny czy antropologii kulturowej, tłumacząca psychofizjologiczne oraz kulturowe podstawy dynamiki samotności i wspólnotowych aspektów istnienia i działania człowieka. Ponadto obok powagi rozważań teologicznych, o których była mowa powyżej, znajdziemy w recenzowanej pracy swoistą lekkość odniesień do literatury pięknej, w tym poezji, wykorzystanie Tischnerowskiej gawędy, opisy obrazów filmowych czy konkretnych obrazów egzystencjalnych. Służą one zawsze swoistej egzemplifikacji podejmowanych kwestii, ukazują realistyczny charakter badanego zagadnienia.

Korzystając $\mathrm{z}$ bogactwa filozoficznej i teologicznej oraz zawartej w innych dobrach kulturowych wiedzy, autorka tworzy jednocześnie pracę na wskroś pedagogiczną. Owa pedagogiczność wiąże się z całościowo ujętą rzeczywistością wychowania, nie ogranicza się do poznania aspektowego, niesie też wysiłek odniesień do przyszłej praktyki. Jak podkreślał przed laty Kazimierz Sośnicki (chociażby w pracy: Istota i cel wychowania), pedagogika dąży do ujęcia wychowania przez pryzmat złożoności jego uwarunkowań. Logicznie tłumaczył, że owa złożoność nie jest tym samym co suma uwarunkowań. Dlatego prawidłowo kreowana pedagogika nie jest zlepkiem 
wiedzy z zakresu innych nauk (choć do nich nierzadko nawiązuje), które w poznaniu aspektowym również badają wychowanie, ale tworzy całkiem nową oryginalną jakość wiedzy o wychowaniu. Współcześnie między innymi Dariusz Kubinowski podkreśla ową niepowtarzalną wartość wiedzy pedagogicznej, wypływającą z tworzenia przez pedagogikę wiedzy holistycznej - ujmującej wychowanie i jego uczestników właśnie w sposób całościo$w^{1}$. Takie poznanie respektuje zasady realizmu, próbuje oddać rzeczywisty, a nie zredukowany obraz swojego przedmiotu. Ten niezwykle poważny trud holistycznego ujęcia rzeczywistości wychowawczej w perspektywie zagadnienia samotności i wspólnotowości ludzkiego istnienia i działania stał się z powodzeniem udziałem Małgorzaty Wałejko, a jego owoce zostały ukazane $\mathrm{w}$ recenzowanej pracy.

Wracając do punktu pierwszego - wykorzystania w pracy wiedzy filozoficznej - Autorka jasno wskazuje na filozofię chrześcijańskiego personalizmu jako na tę, która daje podstawy dla prowadzonych analiz - stwarza dla nich ,horyzont interpretacji”. Ucieczka od jasnego wskazania podstaw filozoficznych w kreowaniu wiedzy pedagogicznej na ogół świadczy o słabości warsztatowej pedagoga, o jego ignorancji lub nieświadomości, że oto nie nazywając ,po imieniu” lub nie rozpoznając własnych założeń ontologicznych czy epistemologicznych i tak zawsze przyjmuje określoną filozofię widzenia świata i poznawania go. Tyle że takiej nieuświadomionej czy pomijanej przez siebie „filozofii” na ogół nadaje się rysy dyletanckie, prymitywne. Małgorzata Wałejko z wielką pieczołowitością stwarzała filozoficzny fundament wypracowanej w całej rozprawie wiedzy pedagogicznej. Na nim nadbudowywała kolejne piętra tej wiedzy, niekiedy sięgając do innych nauk, wypracowując elementy ogólnej teorii wychowania czy też pedagogiki praktycznej, wskazując na kwestie normatywne i metodyczne.

Recenzowana tu praca Małgorzaty Wałejko ma znamiona dojrzałego dzieła pedagogicznego. Stanowi lekturę niezwykle interesującą, choć również bardzo trudną - wymagającą głębokiego zaangażowania intelektualnego, emocjonalnego i duchowego czytelnika. Przedstawia wyjątkową wartość poznawczą dla teoretyków wychowania, prowadząc ich przez kolejne piętra wiedzy pedagogicznej. Niepodważalne jej walory łączą się również z odniesieniami do realnych problemów wychowania. W związku z tym praca ta powinna być również frapującą lekturą dla (wrażliwych i ambitnych) wy-

${ }^{1}$ Dariusz Kubinowski, „Pedagogiczne myślenie humanistyczne jako kategoria metodologiczna", w: Metodologia pedagogiki zorientowanej humanistycznie, red. Dariusz Kubinowski, Marian Nowak (Kraków: Oficyna Wydawnicza „Impuls”, 2006), 171-187. 
chowawców. Jednym i drugim (teoretykom i praktykom) lektura ta przybliża kolejne tajniki samotności i wspólnotowości jako wymiarów ludzkiej egzystencji, a jednocześnie najważniejszych wyzwań w dziele wychowania.

Lucyna Dziaczkowska*

\section{Bibliografia}

Kubinowski, Dariusz. „Pedagogiczne myślenie humanistyczne jako kategoria metodologiczna". W: Metodologia pedagogiki zorientowanej humanistycznie, red. Dariusz Kubinowski, Marian Nowak, 171-187. Kraków: Oficyna Wydawnicza „Impuls”, 2006.

Wałejko, Małgorzata. Osobno i razem. Personalistyczne wychowania do samotności $i$ wspólnoty. Szczecin: Wydawnictwo Naukowe Uniwersytetu Szczecińskiego, 2016.

\section{Walt Larimore, Barb Larimore, Jej mózg, jego mózg czyli Bóg wie, co robi, Poznań: W drodze, 2016, s. 254.}

DOI: http://dx.doi.org/10.12775/PCh.2017.018

Od czasu wydania w 1989 roku jednej z najważniejszych książek dotyczących różnic pomiędzy mężczyzną a kobietą, czyli Ptci mózgu. O prawdziwej różnicy między mężczyzna a kobieta (oryg. Brain Sex. The Real Difference Between Men and Women), minęło już ponad 25 lat. Od tamtego czasu w społecznym postrzeganiu płci, męskości i kobiecości wydarzyło się sporo, by wspomnieć tylko o zakrojonej na szeroką skalę promocji ideologii gender i związanego z nią ruchu LGB (T,Q itd.), ostatnio przemianowywanego na MOGAI (ang. Marginalized Orientations, Gender identities, And Intersex), gdyż do pierwotnego skrótu LGB dodawano kolejne kategorie, co ostatecznie doprowadziło do skonstruowania tworu literowego LGBTQIAP+ (w języku ang. Lesbian, Gay, Bisexual, Transgender and Two-spirited, Queer and Questioning, Intersex, Asexual, Pansexual and other marginalized orien-

* Dr hab. Lucyna Dziaczkowska, prof. KUL, pracuje w Katedrze Pedagogiki Porównawczej i Filozofii Wychowania w Instytucie Pedagogiki Katolickiego Uniwersytetu Lubelskiego Jana Pawła II. Adres: Instytut Pedagogiki KUL, ul. Droga Męczenników Majdanka 70, 20-325 Lublin; e-mail: ldziaczkowska@kul.lublin.pl. 